Colonising Egypt 
This page intentionally left blank 


\section{Colonising Egypt}

\section{TIMOTHY MITCHELL}

New York University 
University of California Press

Berkeley and Los Angeles, California

University of California Press, Ltd.

London, England

C Cambridge University Press 1988

First paperback printing 1991

Library of Congress Cataloging-in-Publication Data

Mitchell, Timothy.

Colonising Egypt/Timothy Mitchell.

p. $\mathrm{cm}$.

Reprint. Originally published: Cambridge, Cambridgeshire ; New

York : Cambridge University Press, 1988. With new pref.

Includes bibliographical references and index.

ISBN 978-0-520-07568-9 (alk. paper)

1. Egypt-Relations-Europe. 2. Europe-Relations-Egypt.

3. Egypt-Civilization-1798-I. Title.

DT 100.M57 1991

$303.48^{\prime} 26204 \mathrm{dc} 20 \quad 91-15090 \mathrm{CIP}$

Printed in the United States of America

$\begin{array}{lllllllll}15 & 14 & 13 & 12 & 11 & 10 & 09 & 08 & 07 \\ 16 & 15 & 14 & 13 & 12 & 11 & 10 & 9 & \end{array}$

The paper used in this publication is both acid-free and totally chlorine-free (TCF). It meets the minimum requirements of ANSI/NISO Z39.48-1992 (R 1997) (Permanence of Paper). $@$ 
The fundamental event of the modern age is the conquest of the world as picture.

Martin Heidegger, 'The age of the world picture'

This order of appearance is the order of all appearance, the very process of appearing in general. It is the order of truth.

Jacques Derrida, 'The double session' 
This page intentionally left blank 